\title{
STUDI PENDAHULUAN PREPARASI MEMBRAN UNTUK SEL BAHAN BAKAR MEMBRAN ELEKTROLIT POLIMER
}

\author{
MARIA CHRISTINA PRIHATININGSIH*, YOHAN**, NOOR ANIS KUNDARI* \\ *Sekolah Tinggi Teknologi Nuklir - Badan tenaga Nuklir Nasional \\ ** Kementrian Riset dan Teknologi
}

\begin{abstract}
Abstrak
Telah dilakukan preparasi membran penghantar proton untuk sel bahan bakar membran elektrolit polimer (PEMFC) melalui pencangkokan kopolimer dengan cara iradiasi asam akrilat pada polimer induk polietilena linier kerapatan rendah (LLDPE), polietilena kerapatan tinggi (HDPE), dan polipropilena (PP). Kopolimer cangkok dibuat dengan menggunakan iradiasi- $\gamma$ dan iradiasi berkas elektron. Metode yang digunakan dalam pencangkokan adalah metode radikal peroksida dan metode pencangkokan yang diinisiasi oleh radikal terjebak. Reaksi pencangkokan dilakukan setelah proses iradiasi (pre-irradiation grafting). Kemudian dipelajari pengaruh kondisi-kondisi preparasi dan peran matriks polimer induk. Derajat pencangkokan dipengaruhi oleh dosis total selama radiasi, konsentrasi monomer, suhu pencangkokan, dan waktu pencangkokan. Laju dosis tidak terlalu berpengaruh terhadap hasil pencangkokan. Kondisi paling baik untuk pencangkokan adalah dosis total $45 \mathrm{kGy}$, konsentrasi monomer $40 \%(\mathrm{v} / \mathrm{v})$, suhu pencangkokan $70^{\circ} \mathrm{C}$, dan lama pencangkokan 90 menit.Membran dengan matriks polimer berbeda memiliki daya pengembangan dalam air yang berbeda pula. Daya pengembangan dalam air tergantung pada matriks polimer induk. Ini mencerminkan sifat hidrofilik membran. Pengujian daya serap terhadap ion logam dilakukan pada membran cangkok dengan menggunakan analisis teknik spektrometri serapan atom. Daya serap maksimum membran terhadap ion logam secara nonkompetitif menghasilkan $\mathrm{Fe}>\mathrm{Cu}>\mathrm{Co}$, kecuali membran LLDPE-g-AAc daya serap terhadap Co $>\mathrm{Cu}$. Bila ketiga larutan ion logam dicampurkan sebagai satu jenis larutan umpan, daya serap maksimum membran adalah $\mathrm{Fe}>\mathrm{Cu}>\mathrm{Co}$.
\end{abstract}

Kata kunci: Sel bahan bakar membran elektrolit polimer, pencangkokan kopolimer, iradiasi- $\gamma$, berkas elektron, LLDPE, HDPE, dan PP

\begin{abstract}
Proton conducting membranes for polymer electrolyte membrane fuel cells (PEMFC) have been prepared by radiation graft copolymerization of acrylic acid onto back bone polymers such as linear low density polyethylene (LLDPE), high density polyethylene (HDPE), and polypropylene (PP). Graft copolymers are prepared by $\gamma$ radiation and electron beam irradiation. The methods used are grafting on radiationperoxidized and grafting initiated by trapped radicals, in which the grafting reaction
\end{abstract}


is done after the irradiation process (pre-irradiation grafting). The influence of the preparation conditions and the role of the initial polymer matrixes are studied. The degrees of grafting are determined by the total absorbed dose during irradiation, monomer's concentration, grafting temperature, and the time of grafting. It is found that dose rate does not have a significant effect on the yield of grafting. The best suitable conditions for the grafting are as follows: $45 \mathrm{kGy}$ for total dose, $40 \%(\mathrm{v} / \mathrm{v})$ for monomer's concentration, $70^{\circ} \mathrm{C}$ for temperature and 90 minutes for period of grafting. Membranes based on different polymer matrixes show differences in their water uptake from liquid water. Apparently the ability of the membranes to take in the solvent depends on matrixes of the back bone polymers. It reflects the hydrophilic membranes properties. The preliminary characterization of the prepared grafted membranes is done by the treatment of metal uptake, using atomic absorption technique. The maximum uptake of the membranes for a given metal is $\mathrm{Fe}>\mathrm{Cu}>\mathrm{Co}$ except for LLDPE-g-Aac in which the uptake of $\mathrm{Co}>\mathrm{Cu}$. The maximum uptake of the membranes for a mixture of the metals in the same feed solution is $\mathrm{Fe}>\mathrm{Cu}>\mathrm{Co}$.

Keywords : PEMFC, radiation graft copolymerization, $\gamma$-radiation, electron beam,

LLDPE, HDPE, and PP

\section{PENDAHULUAN}

Sel bahan bakar atau fuel cell adalah satu sumber energi alternatif yang tengah dikembangkan saat ini. Piranti sel bahan bakar dapat menghasilkan listrik langsung melalui proses elektrokimia dengan mengkombinasikan gas hidrogen $\left(\mathrm{H}_{2}\right)$ dan oksigen $\left(\mathrm{O}_{2}\right)$. Struktur fisik dasarnya terdiri atas lapisan elektrolit yang salah satu sisinya merupakan daerah kontak anoda berpori dengan katoda berpori pada sisi lainnya. Sel bahan bakar dibagi atas beberapa kategori berdasarkan kombinasi tipe bahan bakar dan oksidan, tipe elektrolit yang digunakan, temperatur operasi, dan lain-lain (William, 2000). Yang menjadi sasaran dalam penelitian ini adalah polymer electrolyte fuel cell yang bekerja pada temperatur yang relatif rendah.

Polymer electrolyte membrane fuel cells (PEMFC) dapat memberikan densitas daya yang tinggi dan mempunyai kelebihan dalam hal berat dan volume dibandingkan dengan sel bahan bakar jenis lain. PEMFC menggunakan polimer padat sebagai elektrolit dan elektroda karbon berpori (porous carbon electrodes) yang mengandung katalis platina. PEMFC hanya membutuhkan hidrogen, oksigen dari udara, dan air untuk sistem operasinya dan tidak membutuhkan cairan korosif seperti pada sel bahan bakar jenis lain. PEMFC beroperasi pada sekitar $80^{\circ} \mathrm{C}$. Efisiensi PEMFC dapat mencapai 40 $50 \%$, suatu nilai yang jauh melampaui efisiensi mesin bakar BBM yang kurang dari 20\% (Smith, 1971). 


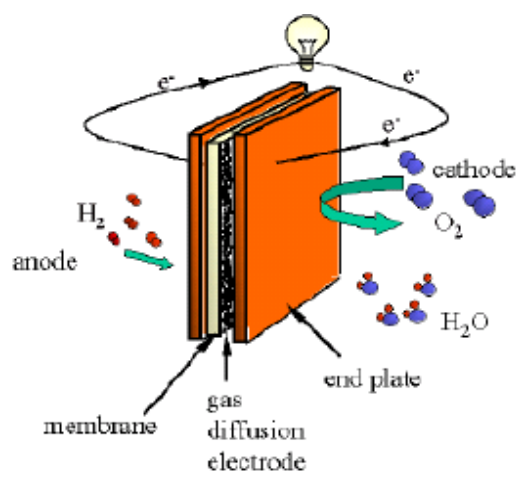

Gambar 1. Skema Sel Bahan Bakar Membran Penghantar Proton (Sumber :

http//www.eere.energy.gov dan Kallio, 2003)

Pada prinsipnya, ada banyak polimer yang bisa dijadikan bahan membran, antara lain; ionomer terfluoronasi. Beberapa perusahaan telah mengembangkan membran perfluorinated seperti Dupont (Nafion ${ }^{\circledR}{ }^{\circledR}$ ) dan Dow Chemical $\left(\right.$ Dow $\left.^{\circledR}\right)$. Kestabilan dan kekerasannya sangat andal sehingga paling banyak digunakan untuk sel bahan bakar. Salah satu metode untuk memodifikasi polimer baik secara kimia maupun fisika adalah proses polimerisasi secara pencangkokan (graft polymerization). Radiasi dapat dijadikan inisiator/induksi pembentuk radikal bebas dan ion pada suatu substrat tertentu kemudian radikal atau ion yang dihasilkan dapat menyebabkan berlangsungnya kopolimerisasi cangkok. Cara seperti ini biasa disebut pencangkokan secara iradiasi (radiation grafting). Beberapa aspek yang harus diperhatikan bila akan menggunakan radiasi dalam aplikasi ke polimerisasi adalah harga G, metode, mekanisme reaksi, derajat pencangkokan, dan sumber radiasi. Secara kuantitatif hasil reaksi kimia radiasi biasanya diistilahkan dengan "harga G” ( $G$ value), yang didefinisikan sebagai banyaknya molekul/spesi yang terbentuk atau terurai akibat penyerapan energi $100 \mathrm{eV}$.

Berdasarkan proses iradiasi, ada dua metode pencangkokan secara iradiasi, yaitu iradiasi polimer dan monomer secara bersamaan (simultan) dan iradiasi secara bertahap (pre-radiation grafting). Teknik iradiasi simultan baik dilakukan apabila monomer tidak lebih reaktif daripada polimernya, sehingga dapat dihindarkan terjadinya homopolimerisasi. Pada teknik iradiasi cara bertahap (pre-radiation grafting), polimer induk diiradiasi terlebih dahulu dalam kondisi vakum atau dalam udara, kemudian ditambahkan larutan monomer yang ingin dicangkokkan. Selanjutnya, dilakukan 
pemanasan pada kondisi bebas oksigen. Oksigen yang mempunyai orbital kosong akan bertindak sebagai penangkap (scavenger) radikal. Mekanisme reaksi rantai pembentukan polimer dalam proses kopolimerisasi dapat dibagi menjadi tiga tahap utama: yaitu inisiasi, propagasi, dan terminas i (Chapiro, 1962, Djojosubroto,1978, dan Fogler 1992): Diperkirakan reaksi yang akan terjadi pada polietilena dalam penelitian ini dapat dilihat pada Persamaan (1) sampai Persamaan (3).

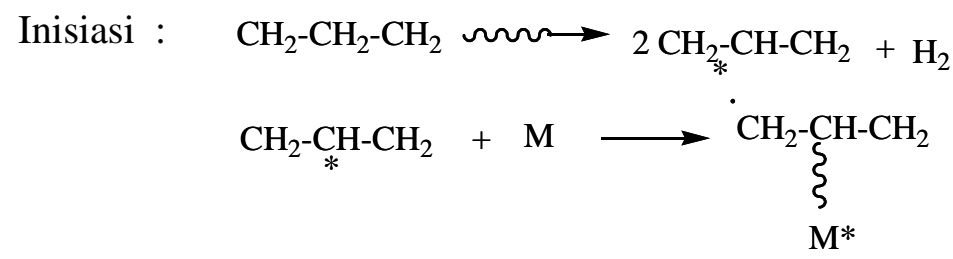

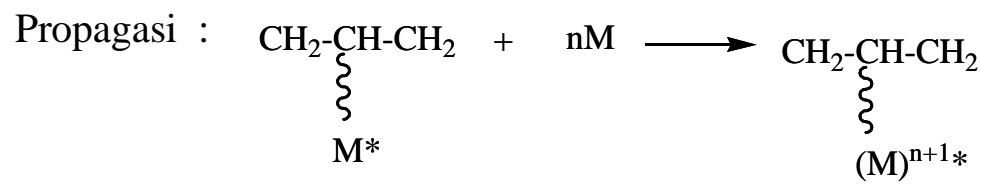

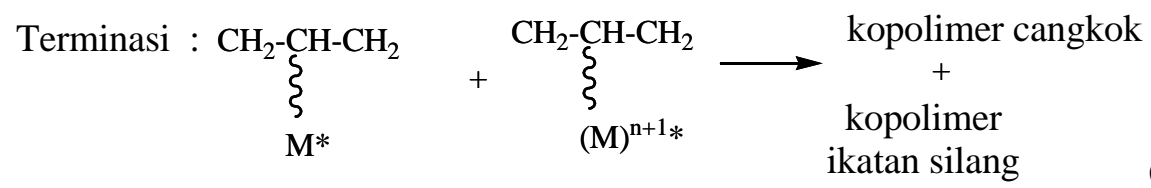

Sumber radiasi yang digunakan dapat berupa sumber radiasi pengion langsung seperti berkas partikel bermuatan dan sumber radiasi berenergi tinggi yang dapat mengionisasi molekul secara tidak langsung, seperti sinar$\mathrm{X}$, dan sinar- $\gamma$.

Yang sering digunakan dalam pencangkokan kopolimer adalah sinar- $\gamma$ dari Co-60, yang mempunyai tingkat energi $1,17 \mathrm{MeV}$ dan 1,33 MeV dengan waktu paruh 5,27 tahun. (Adams dkk., 1970 dan Susetyo, 1988). Fasilitas iradiasi yang dapat mengasilkan sinar- $\gamma$ disebut iradiator- $\gamma$. Selain iradiator- $\gamma$, juga sering digunakan mesin berkas elektron (MBE). Berdasarkan energinya, MBE dibagi menjadi energi rendah ( $\leq 500 \mathrm{keV}$ ), energi menengah (500 keV$5 \mathrm{MeV}$ ), dan energi tinggi ( $>5 \mathrm{MeV}$ ). Dalam proses radiasi dengan berkas elektron, ada tiga parameter utama yang harus diperhatikan, yaitu radiasi berkas elektron, cuplikan yang diradiasi, dan teknik radiasi.

Hasil pencangkokan ditunjukkan oleh DOG (degree of grafting) atau derajat pencangkokan yang didefinisikan sebagai massa monomer yang ditambahan ke matriks film. Derajat pencangkokan dilambangkan dengan angka banding berat setelah pencangkokan dibagi berat sebelum 
pencangkokan atau dalam persentasi dari pertambahan berat dibagi berat awal, ditunjukkan oleh Persamaan (4).

$$
\mathrm{DOG}=\frac{\mathrm{m}_{\text {grafted }}-\mathrm{m}_{\text {initial }}}{\mathrm{m}_{\text {initial }}} \times 100 \%
$$

dengan $\mathrm{m}_{\text {grafted }}$ adalah berat setelah pencangkokan, dan $\mathrm{m}_{\text {initial }}$ adalah berat sebelum pencangkokan dalam gram.

Untuk mengetahui bahwa suatu membran film bersifat hidrofilik atau tidak, dapat dilakukan pengujian daya pengembangan membran film (swelling) dalam air. Daya pengembangan ini dipengaruhi oleh derajat pencangkokan dan gugus hidrofilik yang terbentuk. Derajat daya pengembangan ditunjukkan pada Persamaan (5).

$$
\mathrm{S}(\%)=\frac{\mathrm{S}_{\mathrm{w}}-\mathrm{m}_{\text {grafted }}}{\mathrm{m}_{\text {grafted }}} \times 100 \%
$$

dengan $m_{\text {grafted }}$ adalah berat setelah pencangkokan, dan $S_{w}$ adalah berat film tercangkok setelah direndam dalam air (gram).

Polimer mempunyai bagian molekul yang berbentuk kristalin dan amorf. Bagian yang berbentuk kristal ini disebut kristalinitas polimer. Sifat kristalin dapat membuat polimer bersifat kuat juga rapuh. Bagian amorf dapat memberikan sifat keras pada polimer.

Dalam proses radiasi suatu bahan, dosis radiasi merupakan faktor yang sangat penting. Dosis yang diterima ini tergantung pada laju dosis. Hal yang terkait dengan dosis radiasi adalah keseragaman dosis (dose uniformity) yang dinyatakan dengan perbandingan antara dosis maksimum $\left(D_{\text {maks }}\right)$ dengan dosis minimum $\left(D_{\text {min }}\right)$. Semakin kecil perbedaan antara $D_{\text {maks }}$ dan $D_{\text {min }}$ semakin seragam dosis yang diterima bahan. Bila angka banding $\mathrm{D}_{\text {maks }} / \mathrm{D}_{\text {min }}$ mendekati 1 , maka dosis yang diterima dikatakan seragam.

\section{METODE PENELITIAN}

\section{Bahan dan Peralatan}

Bahan-bahan yang digunakan dalam penelitian ini adalah:

1. Bahan polimer/kopolimer induk adalah Polietilena Linier Kerapatan Rendah (Linear Low Density Polyethylene, LLDPE) dengan struktur $\left[\mathrm{CH}_{2}-\mathrm{CH}_{2}-\mathrm{CHR}-\mathrm{CH}_{2}\right]_{\mathrm{n}}-$, dan Polietilena Kerapatan Tinggi (High Density Polyethylene,HDPE), dengan struktur $-\mathrm{CH}_{2}-\mathrm{CH}_{2}$-poly(ethylene) atau - 
$\mathrm{CH}_{2}$-poly(methylene), didapat dari PT Candra Asri; serta Polipropilena (PP) didapat dari PT Tripolyta dengan struktur

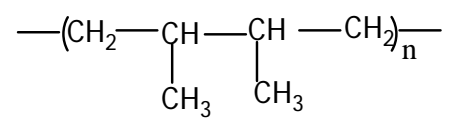

2. Monomer hidrofilik: asam akrilat dan akrilamida ex. Merck.

3. Bahan lain yang digunakan adalah metanol, air demineralisasi, gas nitrogen dengan kemurnian tinggi, silicon grease, ex. Merck yang tahan radiasi, petroleum benzena ex. Merck, dan alkohol teknis 95\%.

Alat yang digunakan untuk penelitian ini meliputi fasilitas sumber radiasi, Iradiator sinar- $\gamma$ IRPASENA dan IRKA, PATIR-BATAN, Jakarta. Seperangkat peralatan gelas khusus penangas air, tabung gas nitrogen dan flowmeter-nya, oven, neraca analitik, peralatan refluks soxlet, pompa vakum dan vacuum controller, peralatan-peralatan gelas laboratorium, papan flexiglass, sebingkai kaca untuk memotong polimer, cutter, penggaris logam, kertas millimeter block, alat dosimetri. Instrumen AAS merk Thermo (STTNBATAN), dan pengukur ketebalan (mikrometer).

\section{Penyiapan Cuplikan}

Cuplikan film LLDPE, HDPE, dan PP dipotong-potong dengan ukuran $3 \mathrm{~cm}$ $\times 4 \mathrm{~cm}$, direfluks dengan larutan alkohol teknis $95 \%$ menggunakan alat soklet selama 6 jam, dikeringkan dalam oven pada suhu $30^{\circ} \mathrm{C}$ selama \pm 2 jam, kemudian ditimbang.

\section{Penyiapan Larutan Monomer}

Larutan monomer asam akrilat dengan konsentrasi tertentu dibuat dengan mengencerkan asam akrilat pekat dengan pelarut air demineralisasi. Larutanlarutan monomer ini selalu dibuat segar dan disimpan dalam botol coklat. Sebelum digunakan dalam proses pencangkokan, larutan monomer ini terus dialiri (diaerasi) gas nitrogen untuk menghilangkan oksigen terlarut.

\section{Iradiasi dan Pencangkokan}

Untuk Metode Radikal Peroksida dengan Iradiator Gamma dilakukan dengan cara; Lembaran-lembaran film LLDPE, HDPE, dan PP yang telah bersih dan ditimbang dimasukkan ke dalam ampul tanpa mengalirkan gas nitrogen atau melakukan pemvakuman. Ampul diiradiasi pada laju dosis dan dosis serap total tertentu. Ampul-ampul yang berisi polimer divakumkan, kemudian dialiri larutan monomer yang telah diaerasi gas nitrogen, kemudian dipanaskan di dalam penangas air pada suhu dan selang waktu tertentu.

Metode radikal terjebak dengan Iradiator Gamma dilakukan dengan cara; lembaran-lembaran film LLDPE, HDPE, dan PP yang telah bersih dan 
ditimbang dimasukkan ke dalam ampul khusus. Ampul divakumkan sampai \pm 8 mbar atau \pm 6 torr selama 30 menit, kemudian dialiri gas nitrogen dengan kemurnian tinggi selama 5-10 menit. Ampul diletakkan di bagian tertentu fasilitas iradiator sesuai dengan laju dosis yang dikehendaki. Iradiasi dilakukan pada waktu tertentu sesuai dosis serap total yang dikehendaki. Segera setelah proses iradiasi selesai, ampul disimpan ke tempat pemvakuman, divakumkan, kemudian dialiri larutan monomer yang telah diaerasi. Ampul yang berisi lembaran film polimer kemudian dipanaskan di dalam penangas air pada suhu dan waktu tertentu.

Cuplikan-cuplikan film LLDPE, HDPE, dan PP yang telah dicangkok dipisahkan dari larutan monomer dan dicuci dengan air demineral panas untuk menghilangkan homopolimer. Setelah itu, cuplikan dikeringkan dalam oven pada suhu $40-50^{\circ} \mathrm{C}$ dan ditimbang sampai beratnya konstan.

Variabel terikat yang dipelajari dalam penelitian ini adalah derajat pencangkokan (DOG). Variabel bebas yang dipelajari adalah variasi dosis (serap) total, variasi laju dosis, variasi konsentrasi monomer, variasi suhu selama pencangkokan, dan variasi lama (waktu) pencangkokan.

Derajat pencangkokan (degree of grafting, $D O G$ ) ditentukan dengan gravimetri berdasarkan pengamatan kenaikan berat seperti pada Persamaan (10).

Daya pengembangan dilakukan dengan cara: Film membran LLDPE, HDPE, dan PP tercangkok yang diketahui berat keringnya direndam dalam air demineral selama satu malam, kemudian dikeringkan dengan cara mengisap film yang basah dengan kertas saring atau kertas isap. Daya pengembangan (swelling) dihitung dengan Persamaan (11).

Pengujian Daya Serap Logam dengan AAS dilakukan dengan cara: Film membran dicelupkan ke dalam larutan umpan standar $\mathrm{Cu}$, Fe, dan $\mathrm{Co}$ 1000 ppm, lalu dibiarkan pada selang waktu 2 jam, 4 jam, 6 jam, dan semalaman. Larutan umpan $\mathrm{Cu}, \mathrm{Fe}$, dan Co yang tidak terserap diukur dengan Spektrometer Serapan Atom (AAS) dengan metode kalibrasi standar. Persentase daya serap logam (metals uptake) merupakan selisih konsentrasi umpan awal dan konsentrasi umpan sisa.

\section{HASIL DAN PEMBAHASAN}

Dari hasil penelitian dengan metode peroksida menggunakan iradiator- $\gamma$, didapat hasil dengan derajat pencangkokan rendah (Tabel 1). Diduga hal ini terjadi karena banyak homopolimer yang terbentuk dibandingkan dengan metode radikal terjebak. Gugus radikal peroksil $\left({ }^{\circ} \mathrm{OH}\right)$ yang terbentuk cenderung menyebabkan homopolimerisasi. 
Faktor-faktor yang harus diperhatikan pada metode radikal peroksida, adalah laju dosis. Laju dosis kecil adalah kondisi terbaik untuk memperlama waktu difusi oksigen ke dalam polimer sehingga didapat jumlah radikal peroksida yang banyak. Suhu pecangkokan harus lebih tinggi dari $70^{\circ} \mathrm{C}$ sehingga tersedia kalor yang cukup untuk mendekomposisi diperoksida dan hidroperoksida. Diperoksida dan hidroperoksida ini diperlukan untuk produksi radikal peroksida sebagai pengaktivasi pencangkokan.

Tabel 1 Hasil Pencangkokan Dengan Metode Radikal Peroksida

\begin{tabular}{|c|c|c|c|c|c|}
\hline Polimer & Keterangan & $\begin{array}{l}\text { Berat (gram) } \\
\text { Dosis } 15 \text { kGy }\end{array}$ & $\begin{array}{l}\text { DOG } \\
(\%)\end{array}$ & $\begin{array}{l}\text { Berat (gram) } \\
\text { Dosis } 30 \text { kGy }\end{array}$ & $\begin{array}{l}\text { DOG } \\
(\%)\end{array}$ \\
\hline \multirow{2}{*}{ LLDPE } & Sebelum iradiasi & 0,0329 & \multirow{2}{*}{9,42} & 0,0350 & \multirow{2}{*}{0,29} \\
\hline & Setelah iradiasi & 0,0360 & & 0,0351 & \\
\hline \multirow{2}{*}{ HDPE } & Sebelum iradiasi & 0,0244 & \multirow{2}{*}{0} & 0,0231 & \multirow{2}{*}{0} \\
\hline & Setelah iradiasi & 0,0244 & & 0,0231 & \\
\hline \multirow{2}{*}{ PP } & Sebelum iradiasi & 0,0655 & \multirow{2}{*}{0} & 0,0427 & \multirow{2}{*}{0} \\
\hline & Setelah iradiasi & 0,0655 & & 0,0427 & \\
\hline
\end{tabular}

Pengaruh dosis total radiasi terhadap derajat pencangkokan polimer LLDPE, HDPE, dan PP ditunjukkan pada Gambar 2.

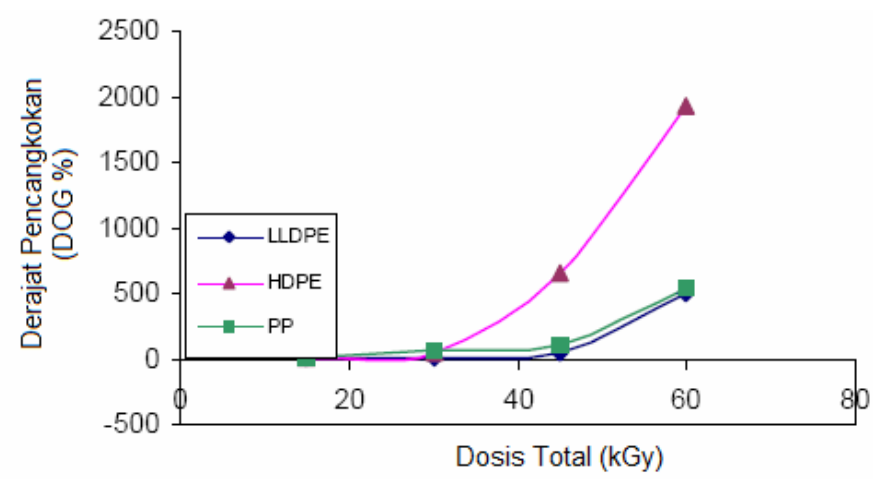

Gambar 2. Pengaruh Dosis Total Terhadap Derajat Pencangkokan

Gambar 2 menunjukkan bahwa derajat pencangkokan meningkat seiring dengan meningkatnya dosis total. Bila diamati dengan saksama, peningkatan dosis total cenderung meningkatkan derajat pencangkokan secara umum, karena dosis radikal bebas yang dihasilkan juga meningkat.

Menurut Hegazy dkk. (1981), peningkatan derajat pencangkokan akan mencapai batas tertentu pada dosis yang lebih tinggi karena adanya 
rekombinasi antara radikal-radikal bebasnya. Pada polimer semi-kristalin, dosis total yang tinggi akan menyebabkan peningkatan kristalinitas (crystallinity). Peningkatan kristalinitas ini akan menurunkan kecepatan difusi monomer pada polimer induk (back bone). Dengan demikian, dosis yang terlalu tinggi akan menurunkan efisiensi inisiasi radikal pada reaksi pencangkokan.

Pengaruh laju dosis pada percobaan ini ditunjukkan pada Gambar 3. Dapat dilihat bahwa pada laju dosis tertinggi $7 \mathrm{kGy} / \mathrm{jam}$ dan laju dosis lebih rendah tidak terdapat perbedaan yang berarti . Pada posisi laju dosis maksimum itu untuk LLDPE dan HDPE didapat derajat pencangkokan yang tinggi, sementara untuk PP di bawah $100 \%$. Laju dosis sangat mempengaruhi proses pencangkokan yang dilakukan dengan metode radikal peroksida. Semakin kecil laju dosis, semakin tinggi derajat pencangkokan yang diperoleh, karena peroksida yang terbentuk lebih banyak dibanding bila iradiasi dilakukan pada laju dosis yang tinggi. Hal ini disebabkan oleh laju dosis kecil, difusi oksigen berlangsung lebih lama.Chapiro (1962).

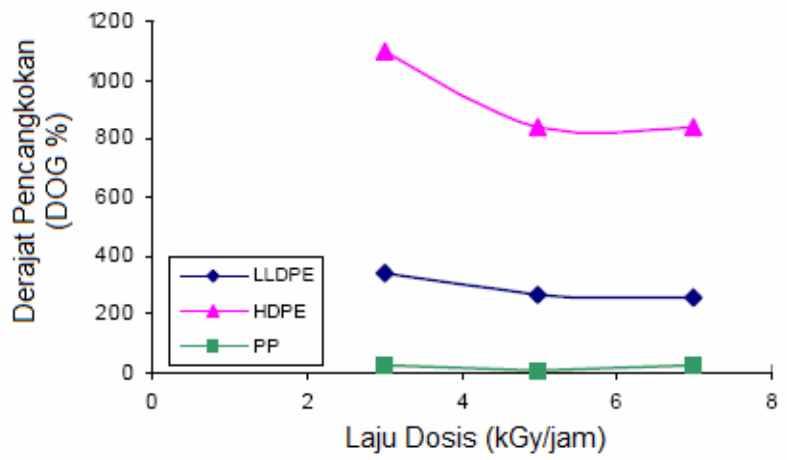

Gambar 3 Pengaruh Laju Dosis Terhadap Derajat Pencangkokan

Salah satu aspek kinetika dan fenomena transfer yang paling berperan dalam metode pencangkokan dengan inisiasi radiasi adalah konsentrasi monomer. Konsentrasi monomerlah yang paling menentukan kinetika proses pencangkokan secara keseluruhan, seperti pada Gambar 4.

Konsentrasi monomer memberi pengaruh terhadap derajat pencangkokan karena berkaitan dengan difusibilitas monomer atau kemampuan monomer berdifusi ke dalam matriks polimer induk. Difusibilitas monomer akan meningkat dengan meningkatnya konsentrasi monomer. Dapat dilihat bahwa derajat pencangkokan terus naik sampai pada konsentrasi monomer asam akrilat 40\%. Pada konsentrasi 50\% terjadi penurunan derajat pencangkokan karena pengaruh viskositas dan meningkatnya laju homopolimerisasi. 


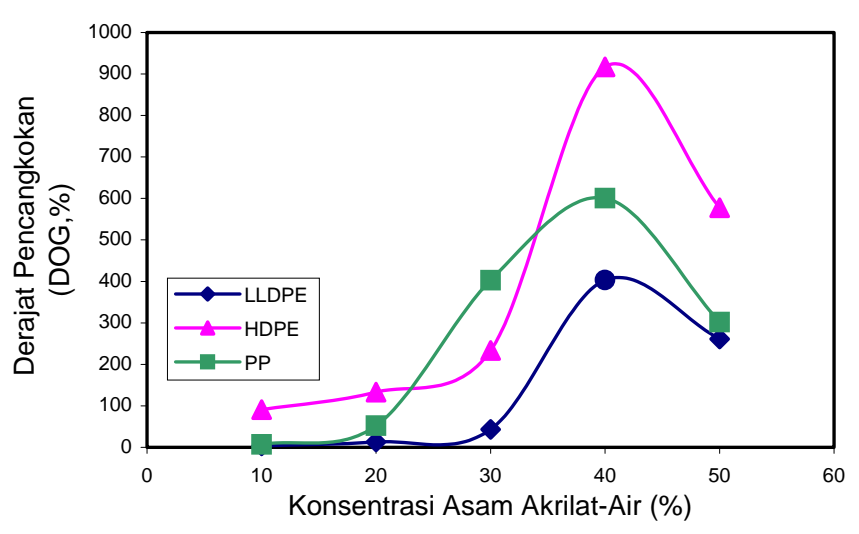

Gambar 4 Pengaruh Konsentrasi Monomer Terhadap Derajat Pencangkokan

Homopolimerisasi adalah peristiwa polimerisasi monomer dengan monomer sejenisnya. Tingginya kadar homopolimer sangat berpengaruh terhadap konsentrasi monomer dan terhadap kemampuan monomer untuk menembus matriks film polimer yang akan dicangkok. Viskositas tinggi dan homopolimerisasi menyebabkan menurunnya mobilitas pertumbuhan rantai kopolimer. Konsentrasi monomer terbaik untuk sistem pencangkokan dengan sistem yang lain tidak selalu sama. Hal itu tergantung pada berbagai faktor seperti jenis pelarut monomer, bahan polimer induk, dosis total, dan laju dosis yang digunakan.

Aspek lain yang berkaitan erat dengan kinetika proses pencangkokan adalah suhu pencangkokan. Dalam hal ini dipelajari suhu pencangkokan $30^{\circ} \mathrm{C}, 50^{\circ} \mathrm{C}, 70^{\circ} \mathrm{C}$, dan $90^{\circ} \mathrm{C}$.

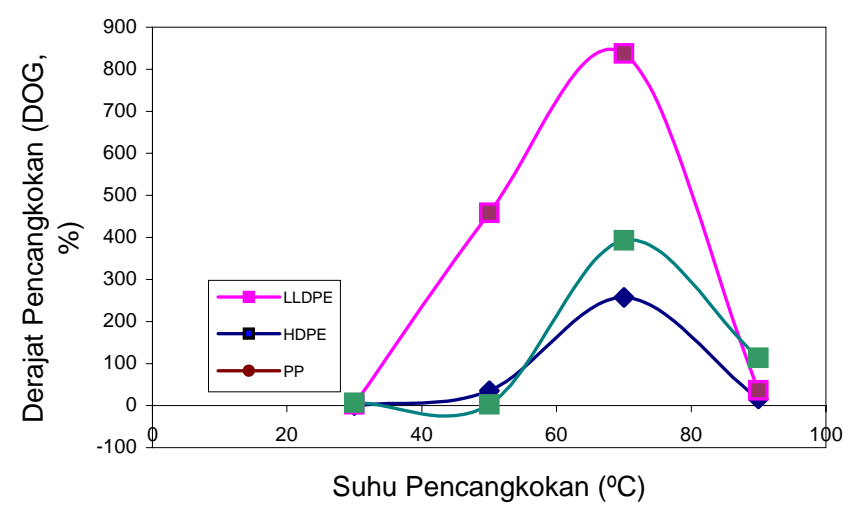

Gambar 5 Pengaruh Suhu Pencangkokan Terhadap Derajat Pencangkokan 
Pada Gambar 5 dapat diamati bahwa pada suhu kamar $\left(30^{\circ} \mathrm{C}\right)$ hingga $70^{\circ} \mathrm{C}$ derajat pencangkokan terus meningkat secara tajam. Tetapi, pada suhu $90^{\circ} \mathrm{C}$ derajat pencangkokan menurun drastis. Penurunan itu dapat disebabkan oleh beberapa kemungkinan, antara lain (a) pada suhu $90^{\circ} \mathrm{C}$ terjadi rantairantai cabang polimer secara cepat pada tahap propagasi, tetapi kemudian cabang-cabang itu terjebak dalam medium viskos karena proses terminasi yang terlalu cepat juga; (b) pada suhu tinggi (bila terjadi difusi udara) terjadi gugus-gugus hidroperoksil yang meningkatkan homopolimerisasi, (c) pada suhu itu bagian-bagian polimer yang bersifat kristalin meleleh dalam medium reaksi.

Suhu pencangkokan memberikan pengaruh secara bersamaan paling tidak terhadap tiga parameter, yaitu (1) kelarutan dan daya difusi, (2) kecepatan atau laju propagasi, dan (3) kecepatan terminasi rantai yang merupakan kontrol pada proses difusi monomer. Hal itu menunjukkan bahwa laju pencangkokan dapat meningkat atau menurun tergantung pada parameter (1) dan (2). Sementara itu, parameter (3) menjadi tahap pengontrol laju atau kecepatan pencangkokan. Dengan demikian, semakin tinggi suhu, kecepatan terminasi rantai juga semakin meningkat (Chapiro, 1962), Menurut Utama (1986), akibat pemanasan pada waktu proses pencangkokan, radikal polimer akan bergerak lebih cepat sehingga reaksi rekombinasi antara radikal akan lebih cepat pula. Di samping itu, antara radikal polimer dan radikal monomer terjadi reaksi aditif yang membentuk kopolimer cangkok yang cepat pula. Di antara peristiwa itu akan terjadi kompetisi.

Waktu pencangkokan mempengaruhi derajat pencangkokan karena berkaitan dengan keleluasaan radikal bereaksi dengan monomer dan difusi monomer ke matriks film polimer induk, seperti yang ditampilkan Gambar 6 .

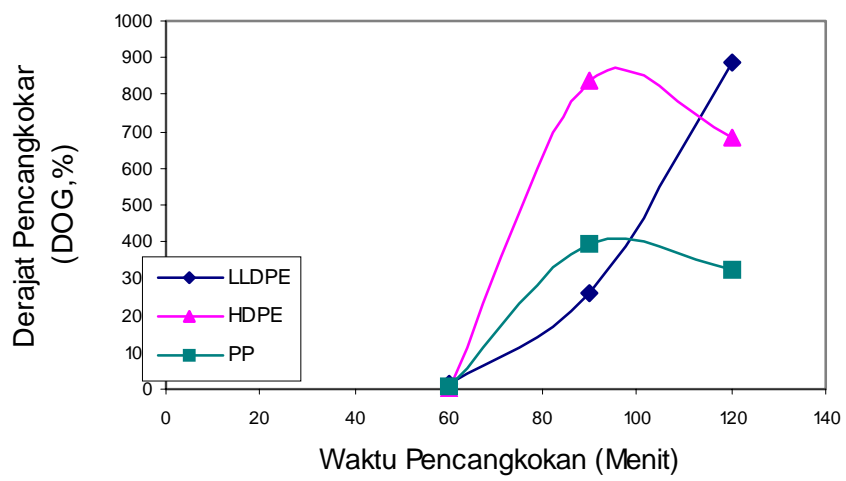

Gambar 6 Pengaruh Waktu Pencangkokan Terhadap Derajat Pencangkokan 
Derajat pencangkokan yang rendah dihasilkan pada waktu pencangkokan yang kurang memberikan keleluasaan radikal-radikal bebas bereaksi dengan monomer. Tetapi waktu pencangkokan yang terlalu lama memberikan bentuk kurva yang datar atau menurun sebagai akibat meningkatnya homopolimerisasi. Terlihat bahwa untuk HDPE dan PP waktu pencangkokan terbaik adalah 90 menit, sedangkan LLDPE masih memperlihatkan kenaikan tajam. Hal ini menunjukkan pengaruh matriks film polimer induk, laju dosis, dan dosis total dalam menghasilkan radikal pada polimer.

Beberapa saat setelah polimer induk teriradiasi, dialiri larutan monomer, dan kemudian dipanaskan dalam water-bath, akan teramati adanya gelembung-gelembung udara kecil dalam ampul. Hal itu menunjukkan adanya evolusi gas sebagai akibat dari radiolisis fragmen-fragmen molekul. Evolusi gas itu berupa pembentukan gas hidrogen. Kemudian, larutan monomer dalam ampul perlahan-lahan mengental. Bersamaan dengan itu, terjadi perubahan dimensi polimer induk secara perlahan-lahan berupa pengembangan (swelling). Pada saat ini juga bisa terjadi homopolimerisasi. Homopolimer diidentifikasi oleh adanya bagian larutan yang lebih kental di dasar ampul pada akhir reaksi. Ketika larutan benar-benar mengental (geleffect), reaksi polimerisasi pun terhenti. Tahap ini disebut tahap terminasi, yaitu keadaan ketika mobilitas monomer benar-benar terhenti. Polimer LLDPE yang telah tercangkok asam akrilat biasa dilambangkan LLDPE-gAAc, untuk polimer HDPE biasa dilambangkan HDPE-g-AAc, dan untuk polimer PP dilambangkan PP-g-AAc.

Asam akrilat bersifat cair, mempunyai bau seperti asam asetat, dan memiliki dua gugus fungsi berupa gugus karboksilat pada posisi $\alpha$ dan ikatan rangkap alkena pada posisi $\beta$. Ikatan rangkap pada asam akrilat membuat senyawa ini dapat bereaksi dengan radikal bebas dalam proses pencangkokan. Gugus karboksilat dapat membuat gugus ini mudah berikatan dengan ion logam. Gambar 7 adalah struktur asam akrilat.<smiles>C=CC(=O)O</smiles>

\section{Gambar 7 Struktur Asam Akrilat}

Polimer yang digunakan dalam penelitian ini adalah polietilena linier dengan kerapatan rendah (LLDPE), polietilena dengan kerapatan tinggi (HDPE), dan polipropilena. Polietilena bersifat nonpolar sehingga larut dalam pelarut polar seperti air. Struktur kristal polimer ini sama dengan struktur normal hidrokarbon parafin (Chapiro, 1962). 


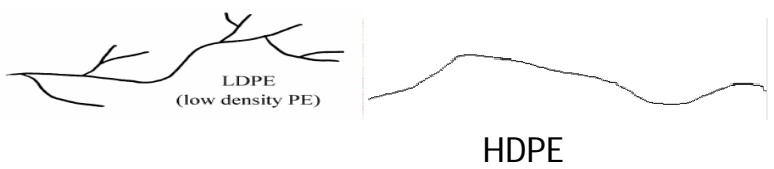

Gambar 8 Struktur LDPE dan HDPE

Polietilena yang banyak mengandung rantai cabang disebut LDPE (low density polyethylene), sedang yang bersifat linier disebut high density polyethylene (HDPE). HDPE lebih kuat, tetapi lebih mahal dari LDPE.

Monomer etilena dapat dikopolimerisasi dengan suatu komonomer cabang alkil menghasilkan kopolimer dengan cabang-cabang hidrokarbon pendek yang sering disebut linear low-density polyethylene (LLDPE) (sumber: http://www.pslc.ws).

Perbedaan kristalinitas juga mempengaruhi proses induksi radiasi. Tetapi, menurut Walsby dkk. (2001), pengaruh kristalinitas terhadap derajat pencangkokan suatu polimer sangat kompleks. Kristalinitas yang tinggi dapat mengurangi daya difusi monomer, sedangkan kristalinitas yang rendah dapat membuat radikal bergerak cepat dan lebih cepat pula memasuki tahap terminasi. Dalam hal ini, polimer HDPE mempunyai bagian yang bersifat kristalin 85\% sampai 95\%, bagian kristalin pada LDPE berkisar 60-70\%, dan bagian kristalin pada LLDPE adalah 33-53\% (http://www.pslc.ws/mactest/crystal.htm; Prasad, 1999; dan Mandelkern dkk., 1999). Karena tingginya kandungan kristal dalam HDPE, dalam penelitian ini derajat pencangkokan pada HDPE selalu cenderung lebih tinggi cenderung lebih besar daripada LLDPE.

Pada saat dicangkok, polipropilena (PP) mengalami perubahan dimensi, tetapi hampir tidak mengalami perubahan bentuk bila dibandingkan dengan HDPE dan LLDPE. Perubahan warna terlihat jelas pada kopolimer PP-g-AAc yang derajat pencangkokannya tinggi dan lebih kaku. Polipropilena lebih banyak menghasilkan homopolimer dibanding polietilena karena PP mengandung sejumlah besar gugus tertier hidrogen, yang pada tahap propagasi cenderung lebih menyukai bentuk hidroperoksida (Chapiro, 1962). Polipropilena yang diperjualbelikan mengandung kristalin 50\%-60\% (http://www.pslc.ws).

Derajat pencangkokan yang didapat dari penelitian ini cukup beragam, berkisar antara 0 sampai dengan $\geq 1000$ untuk LLDPE dan HDPE dan berkisar antara 0 sampai 700 untuk PP. Derajat pencangkokan yang ideal masih dalam perdebatan para peneliti. Derajat pencangkokan yang lebih besar dari $1000 \%$ akan mengurangi kekuatan mekanik membran (Walsby 2001) dan bisa dianggap yang terjadi adalah homopolimer, karena 
perbandingan kandungan polimer dan monomer berkisar satu (1) berbanding 10 .

Pada membran elektrolit polimer, konduktivitas sangat berkaitan dengan sifat-sifat membran seperti kapasitas penukar ion dan kemampuan mengikat air. Air diperlukan untuk melarutkan proton dari gugus-gugus asam. Sebelum pencangkokan, polimer film induk bersifat hidrofobik dan mempunyai berat jenis lebih kecil daripada air. Setelah pencangkokan, polimer film menjadi bersifat hidrofilik dan membentuk kanal-kanal yang dapat mentransfer proton. Hal inilah yang disebut konduktivitas proton. Kemampuan mengikat air ini ditunjukkan dengan daya pengembangan (swelling) membran dalam air, yang dipengaruhi oleh derajat pencangkokan, kristalinitas, matriks membran polimer, dan jumlah gugus hidrofilik, namun tidak terlalu dipengaruhi oleh dosis total pada saat iradiasi awal. Gambar 9, Gambar 10, dan Gambar 11 menunjukkan kemampuan membran polimer LLDPE-g-AAc, HDPE-g-AAc, dan PP-g-AAC dalam mengikat air.

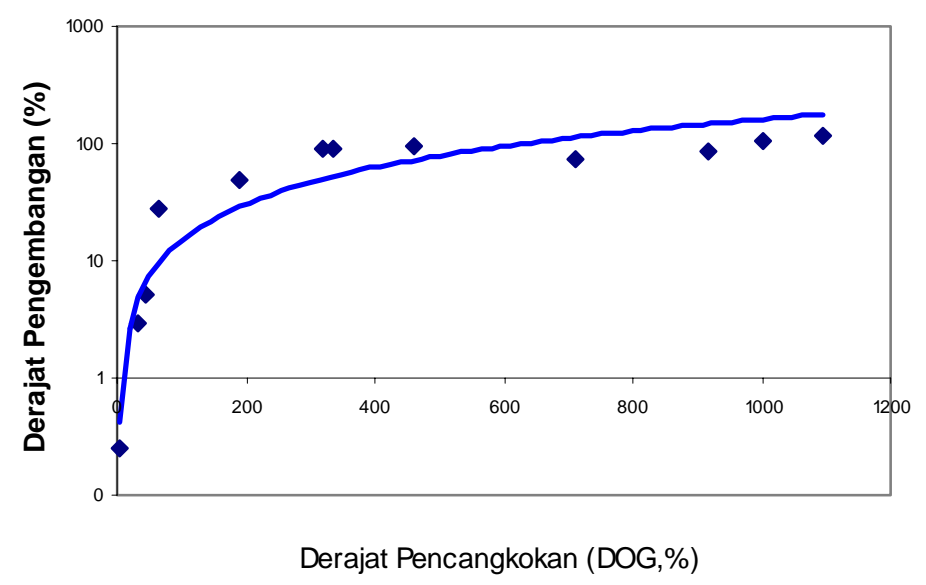

Gambar 10 Hubungan Antara Daya Pengembangan Membran Polimer HDPE-g-AAc dalam Air dengan Derajat Pencangkokan

Kelompok polimer ikatan silang, bila diradiasi, akan cenderung berubah menjadi lebih banyak fase amorfnya. Fase amorf pada polimer lebih mudah menarik air dibanding fase kristalin ( Walsby dkk., 2001). Studi mengenai kemampuan mengikat air atau daya pengembangan (swelling) membran dalam air akan sangat berguna dalam aplikasi manajemen air dalam PEMFC dan DMFC (direct methanol fuel cell). 


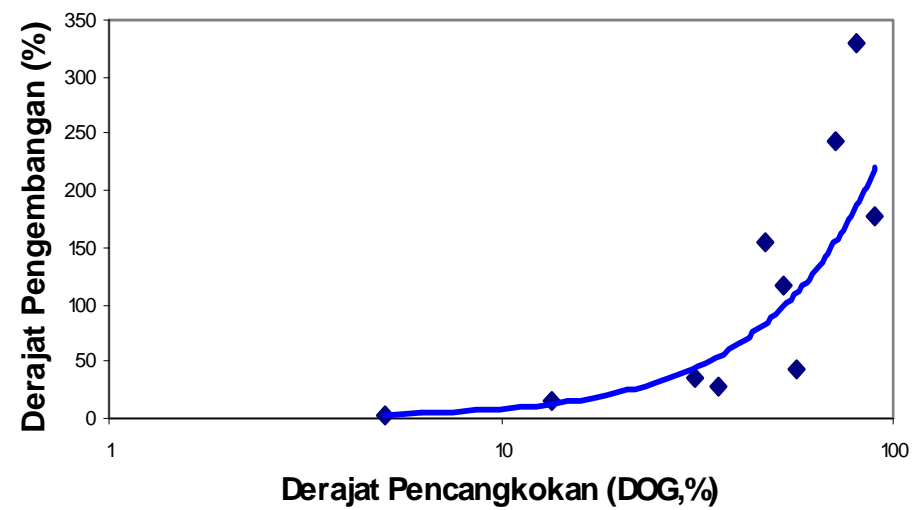

Gambar 10 Hubungan Antara Daya Pengembangan Membran Polimer LLDPE-g-AAc dalam Air dengan Derajat Pencangkokan

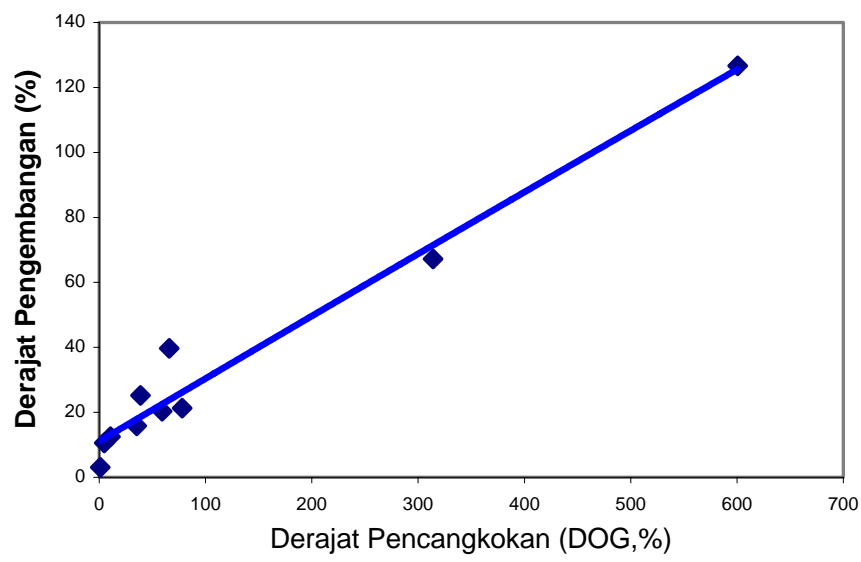

Gambar 11 Hubungan Antara Daya Pengembangan Membran Polimer PP-gAAc dalam Air dengan Derajat Pencangkokan

Daya ikat membran LLDPE-g-AAc, HDPE-g-AAc, dan PP-g-AAc tersebut terhadap ion-ion logam dapat dijadikan gambaran tentang kapasitas penukar ion membran. Gambar 12, Gambar 13, dan Gambar 14 masing-masing memperlihatkan jumlah ion $\mathrm{Cu}$, Fe, dan $\mathrm{Co}$ yang terserap setelah membran kopolimer LLDPE-g-AAc, PP-g-AAc, dan HDPE-g-AAc dikontakkan dengan variasi waktu 1 jam, 3 jam, 6 jam, 8 jam, dan 24 jam. 


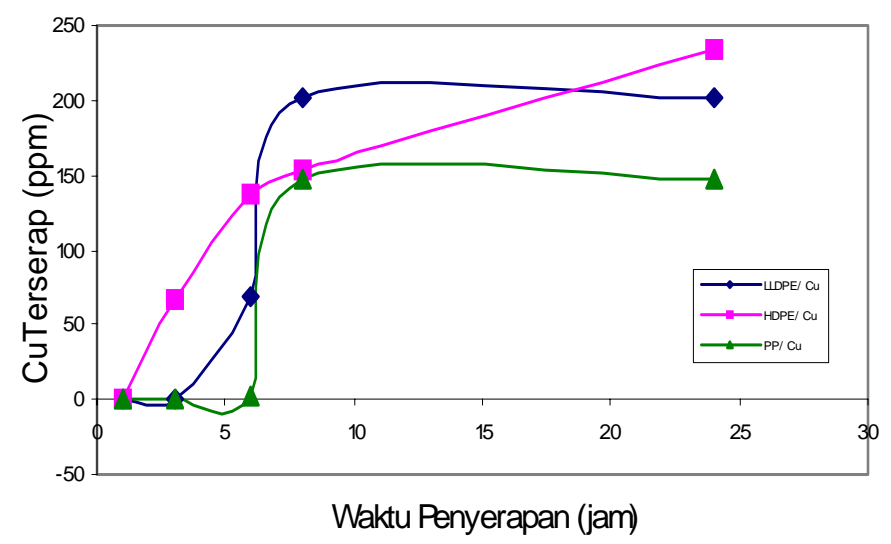

Gambar 12 Hubungan Ion Cu Terserap dengan Waktu Penyerapan

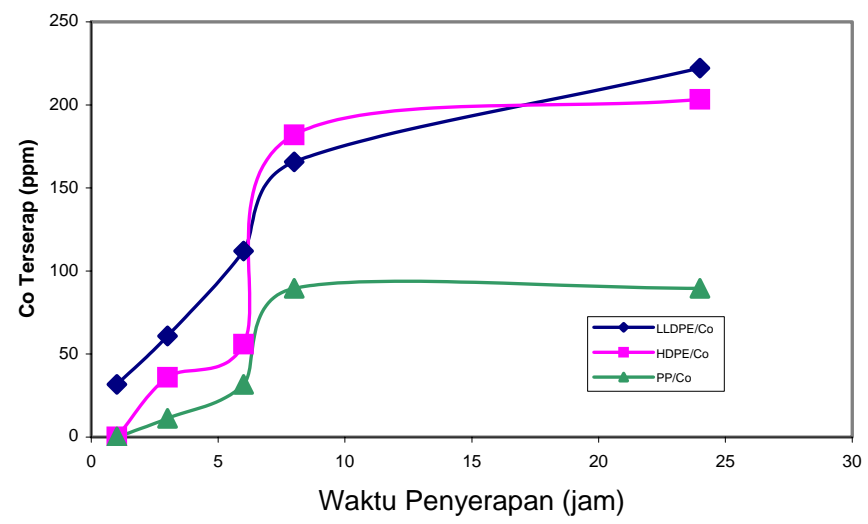

Gambar 13 Hubungan Ion Co Terserap dengan Waktu Penyerapan 


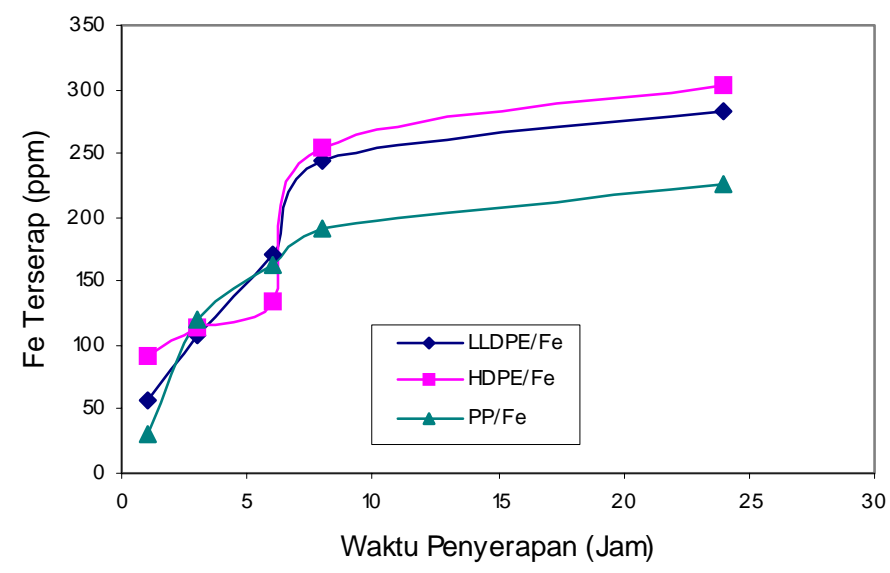

Gambar 14 Hubungan Ion Fe Terserap dengan Waktu Penyerapan

Daya penyerapan membran kopolimer LLDPE-g-AAc, HDPE-g-AAc, dan PP-g-AAc terhadap ion logam $\mathrm{Cu}$, Fe dan Co akan meningkat seiring dengan semakin lama waktu penyerapan. Setelah dua puluh empat jam, penyerapan mencapai kesetimbangan, yaitu daya penyerapan membran kopolimer LLDPE-g-AAc, HDPE-g-AAc, dan PP-g-AAc terhadap ion logam tidak mengalami kenaikan yang berarti. Gugus karboksilat pada membran ini merupakan gugus penukar kation asam lemah yang dapat bekerja dengan baik pada $\mathrm{pH}$ tinggi seperti resin penukar kation asam lemah pada umumnya (Nachad dkk. 1956; Sujadi,1999; Hegazy,1999). Contoh reaksinya diperlihatkan pada Persamaan (6).

$$
\text { Resin- } \mathrm{COOH}+\mathrm{NaOH} \rightarrow \text { Resin-COONa }+\mathrm{H}_{2} \mathrm{O}
$$

Gambar 15 memperlihatkan kemampuan serap maksimum membran kopolimer LLDPE-g-AAc, HDPE-g-AAc, dan PP-g-AAc terhadap ion logam $\mathrm{Cu}, \mathrm{Fe}$, dan Co bila masing-masing membran diserapkan dengan sejenis larutan ion logam. Dapat dilihat bahwa membran HDPE-g-AAc cenderung menyerap ion logam lebih besar daripada LLDPE-g-AAc dan PP-g-AAc. Hampir semua membran menyerap ion logam $\mathrm{Fe}$ lebih besar daripada terhadap ion logam $\mathrm{Cu}$ dan Co. 


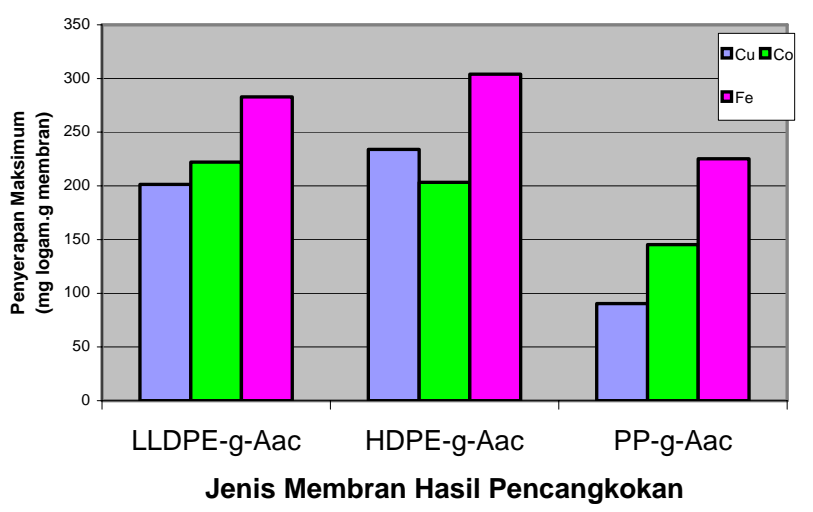

Gambar 15 Daya Serap Maksimum Membran Hasil Pencangkokan

Terhadap Ion Logam Cu, Fe, Dan Co (Nonkompetitif)

Gambar 16 memperlihatkan daya serap maksimum membran kopolimer LLDPE-g-AAc, HDPE-g-AAc, dan PP-g-AAc bila ion logam $\mathrm{Cu}$, Fe, dan Co diserapkan secara bersama-sama (kompetisi). Ternyata bila ion-ion logam itu berada secara bersamaan, membran hasil pencangkokan akan cenderung menyerap lebih banyak Fe, kemudian $\mathrm{Cu}$. Penyerapan terhadap ion Co cenderung kecil untuk membran LLDPE-g-AAc, bahkan tidak menyerap. Gambar 18 juga memperlihatkan selektivitas membran terhadap ion logam tertentu.

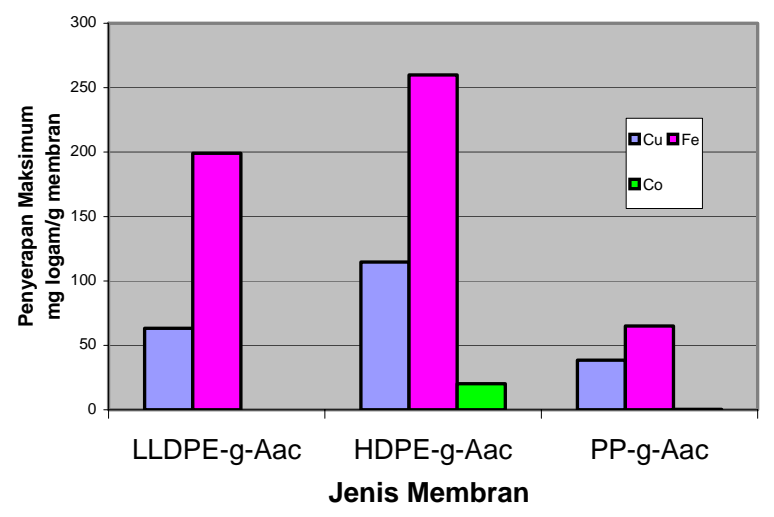

Gambar 16 Daya Penyerapan Maksimum Membran Kopolimer LLDPE-gAAc, HDPE-g-AAc, dan PP-g-AAc Terhadap Ion Logam Cu, Fe, dan Co Secara Kompetitif

Ada dua faktor yang menyebabkan membran kopolimer LLDPE-g-AAc, HDPE-g-AAc, dan PP-g-AAc lebih menyukai Fe dari pada ion $\mathrm{Cu}$ dan Co. 
Pertama adalah daya migrasi dan yang kedua adalah afinitas elektron ion-ion logam Fe, Co dan $\mathrm{Cu}$. Daya migrasi ion logam Fe lebih besar karena berat atom Fe lebih kecil dari Co dan $\mathrm{Cu}(\mathrm{BA} \mathrm{Fe}=56,85$; $\mathrm{BA} \mathrm{Co}=58,93$ dan $\mathrm{Cu}=$ 63,55). Makin kecil berat atom suatu ion logam, maka ion logam itu akan makin mudah bergerak. Afinitas elektron Fe adalah 24, Co adalah 70 dan $\mathrm{Cu}$ adalah 118,3 (Bodner dkk., 1989). Untuk suatu ion logam makin kecil afinitas elektronnya makin besar afinitas protonnya. Ion $\mathrm{Fe}$ mempunyai afinitas elektron yang kecil dibanding ion $\mathrm{Co}$ dan $\mathrm{Cu}$ sehingga afinitas terhadap membran penukar kation lebih besar dibanding ion-ion $\mathrm{Co}$ dan $\mathrm{Cu}$.

Dalam proses iradiasi polimer induk LLDPE, HDPE dan PP, dosis (serap) total merupakan faktor yang sangat penting. Dosis yang diterima tergantung pada laju dosis, yaitu jumlah dosis total dibagi satuan waktu. Untuk keperluan pencangkokan ini, telah diamati beberapa kali pengukuran dosis total seperti pada Tabel 2.

Tabel 2 Dosis Total Beberapa Kali Pengukuran Dengan Dosimetri CTA

\begin{tabular}{cccc}
\hline No & Dosis Total (kGy) & No & Dosis Total (kGy) \\
\hline 1. & 41,11 & 6. & 51,27 \\
2. & 43,15 & 7. & 52,23 \\
3. & 54,67 & 8. & 54,88 \\
4. & 51,67 & 9. & 47,63 \\
5. & 56,78 & 10. & 55,75 \\
\hline
\end{tabular}

Bila dihitung secara statistik, untuk dosis total yang diinginkan sebesar 45 $\mathrm{kGy}$, sebanyak 10 kali pengamatan dosimetri, didapat $\mathrm{D}_{\text {maks }}=56,78 \mathrm{kGy}$, $\mathrm{D}_{\min }=41,11 \mathrm{kGy}$, standar deviasi $+5,07$, penyimpangan relatif 9,93\%, dengan keseragaman dosis $D_{\text {maks }} / D_{\min }=1,38$. Dalam penelitian ini penyimpangan relatif terhadap keseragaman dosis mendekati nilai $10 \%$.

\section{KESIMPULAN}

Studi pendahuluan preparasi membran untuk sel bahan bakar elektrolit membran polimer telah dilakukan dengan kesimpulan sebagai berikut:

1. Telah didapat membran LLDPE-g-AAc, HDPE-g-AAc, dan PP-g-AAc hasil pencangkokan-iradiasi dengan metode radikal terjebak, walaupun percobaan dilakukan dengan berat cuplikan relatif kecil (20-80 mg). Membran kopolimer cangkok ini mempunyai sifat yang berbeda dengan polimer induk sebelumnya. Polimer induk sebelumnya bersifat hidrofobik, sedangkan membran hasil modifikasi bersifat hidrofilik.

2. Kondisi terbaik pada pencangkokan secara iradiasi ini adalah dosis total $45 \mathrm{kGy}$, konsentrasi monomer $40 \%$, suhu pencangkokan $70^{\circ} \mathrm{C}$, waktu pencangkokan 90 menit, dan laju dosis 7 kGy/jam. 
3. Bila penentuan kapasitas serap terhadap ion logam dilakukan secara tunggal, tampak bahwa pada membran HDPE-g-AAc dan PP-g-AAc penyerapan terhadap Fe lebih besar dari $\mathrm{Cu}$ lebih besar dari Co, kecuali pada LLDPE-g-AAc penyerapan terhadap Co lebih besar dari $\mathrm{Cu}$. Bila penentuan kapasitas serap terhadap ion logam dilakukan secara kompetisi pada semua membran, maka penyerapan terhadap Fe lebih besar dari $\mathrm{Cu}$ lebih besar dari Co.

\section{DAFTAR PUSTAKA}

1. Adams dan Dams, 1970, Applied Gamma-Ray Spectrometry, Pergamon Press, Oxdord, England

2. Bodner dan Pardue, 1989, Chemistry an Experimental Science, John Wiley and Sons, Toronto, Singapore

3. Chapiro, A., 1962, Radiation Chemistry of Polymer, Interscience Publishers, London

4. “Crystallinity in Polymers”, 2002, http://www.pslc.ws/mactest/ crystal.htm, diakses April 2005

5. Djojosubroto, H., 1978, "Polimerisasi dengan Radiasi: Kimia Radiasi Zat Organik”, Pengantar Ilmu Pengetahuan dan Teknologi Nuklir, BATAN, hlm.176-178

6. Fogler, H.S., 1992, Element of Chemical Reaction Engineering, Edisi ke-2, Prentice-Hall International, Inc., New Jersey

7. “Fuel Cells: Types of Fuel Cells”, http://www.eere.energy.gov , diakses 28 Juli 2004

8. Hegazy, A., Ishigaki, I., Rabie, A., Dessouki, M. A., dan Okamoto, J., 1981, "Study on Radiation Grafting onto Fluorine-Containing Polymers II, Properties of Membrane Obtained by Preirradiation Grafting onto Poly(tetrafluoroethylene)”, Journal of Applied Polymer Science, Vol. 26, John Wiley \& Sons, Inc.

9. Hegazy, A., Taher, N.H., dan Ebaid, A.R., 1990, "Radiation-Initiated Graft Copolymerization of Individual Monomer and Comonomer onto Polyethylene and Polytetrafluorothylene Films”, Journal of Applied Polymer Science, Vol. 30, John Wiley \& Sons, Inc.

10. Hegazy, A., Abd El-rehim, H. A., dan Shawsy, H. A., 1999, “ Investigation and Characterization of Radiation grafted Copolymers for Possible Practical Use in Waste Water Treatment”, Radiation Physics and Chemistry, Elsevier Science Ltd., Pergamon

11. “IZOTOP Gamma Irradiator”, http://www.izotop.hu/radtech/ radtech6.htm, diakses 2 April 2005 
12. Kallio, T., 2003, "Electrochemical and Physicochemical Characterization of Radiation-Grafted Membranes for Fuel Cells”, Disertasi doktoral, Helsinki University of Technology

13. Mandelkern, L., dan Alamo, R.G., 1999, "Polyethylene, Linier High-density”, Polymer Data Handbook, Oxford University Press, Oxford

14. Nachad, F.C., dan Schubert, J., 1956, Ion Exchage Technology, Academic Press Inc. Publisher, New York

15. "Opening Doors to Fuel Cell Commercialisation: 3,000 Kilometres on 2kg of Hydrogen”, http://www.fuelcelltoday.com, diakses 1 Februari 2005

16. Prasad, A., 1999, "Polyethylene, Linier Low-density”, Polymer Data Handbook, Oxford University Press, Oxford

17. Sujadi, P., 1999, "Kopolimerisasi Cangkok Asam Akrilat pada Film Polietilena Kerapatan Rendah (LDPE) dengan Teknik Iradiasi Awal dalam Udara”, Karya Utama S-1, Fakultas MIPA, Jurusan Kimia, Universitas Indonesia, Jakarta

18. Smith, N. O., 1971, Chemical Thermodinamics, Reinhold Publishing Corporation, New York

19. Utama M., Juli 1986, "Penempelan Campuran Monomer Akrilonitril-Stirena Pada Rayon Iradiasi”, Majalah BATAN Vol XVII, No. 2

20. Walsby, N., 2001, "Preparation and Characterisation of Radiation-Grafted Membranes for Fuel Cells”, Disertasi doktoral, Helsinki University of Technology

21. Walsby, N., Sundholm, F., Kallio, T., dan Sundholm, C., 2001, "RadiationGrafted Ion-Exchange Membranes: Influence of the Initial Matrix on the Synthesis and Structure”, Journal of Polymer Science, Part A, Vol 29, John Wiley \& Sons, Inc.

22. William, M. C., 2000, Fuel Cell Handbook, Edisi ke-5, US Department of Energy, Morgantown, West Virginia 
